\title{
Testing the Reliability of Anatomical and Epidermical Characters in Grass Taxonomy
}

\author{
M. Cristina*, A. Dinis* and F. Sales* \\ * Department of Botany \& IAV, University of Coimbra, 3001-456 Coimbra, Portugal. \\ Mara_lacristina@hotmail.com
}

Grasses are simplified plants and the leaf is one of the few organs that provides taxonomic characters. Leaf anatomy and epidermis (and associated structures) have been used as characters in taxonomy of Poaceae since the 1930s [1]. Such characters became well-established and accepted in the 1960s with Metcalfe's investigations [2]. However, recent research casts doubts on the consistency and reliability of such characters [e.g. 3]. Grasses are highly adaptable plants due to their marked phenotypic plasticity [4]. In order to assess the reliability of leaf characters, species that occur in very contrasting habitats constitute the ideal case study. Corynephorus canescens (L.) P.Beauv. and Antinoria agrostidea (DC.) Parl. were selected; the former occurs from coastal sandy dunes to high altitude, the latter survives submerged and in ponds that dry-out during summer.

Three accessions for each species and for each habitat were investigated. Leaf blades were treated following our modified versions of the methods described by Dop \& Gautié [5] and Halbritter [6]. SEM observations were under a JEOL JSM T220. Analysis of structures was standardized [7, 8].

A number of leaf characters proved to be plastic. Density of exodermic elements is higher (Figure 1. A-B) and sclerenchyma more developed in the driest habitats. Bulliform cells are far more developed in Antinoria growing in dry conditions than in submerged plants; in Corynephorus bulliform cells are poorly developed whatever the water available. Number and width of vascular bundles seems to vary with temperature: more and wider in Corynephorus at the warmer sea level (Figure 2. A-B) and in submerged, more protected from the altitudinal low night temperatures, in Antinoria.

Although phenotypic plasticity does not dramatically alter leaf structure, the observed environmentally induced modifications indicate to careful evaluation of variation prior to its use in the taxonomy of grasses.

\section{References}

[1] H. Prat, L'épiderme des graminées. Étude anatomique et systématique, Massion et $C^{\text {ie }}$, Paris, 1931.

[2] C.R. Metcalfe, Anatomy of the Monocotyledons. I. Gramineae, Clarendon Press, Oxford, 1960.

[3] S.G. Aiken, L.P. Lefkovitch, Can. J. Bot., 62 (1984) 1864-1870.

[4] M. Dubé, P. Morisset, Can. J. Bot., 74 (1996) 1708-1718.

[5] P. Dop, A. Gautié, Manuel de Technique Botanique, F.R. Rudeval, Paris, 1909.

[6] H. Halbritter, Biotechnic \& Histochemistry, 73 (1998) 137-143.

[7] R.P. Ellis, Bothalia 12 (1979) 641-671.

[8] R.P. Ellis, Bothalia 12 (1976) 65-109. 


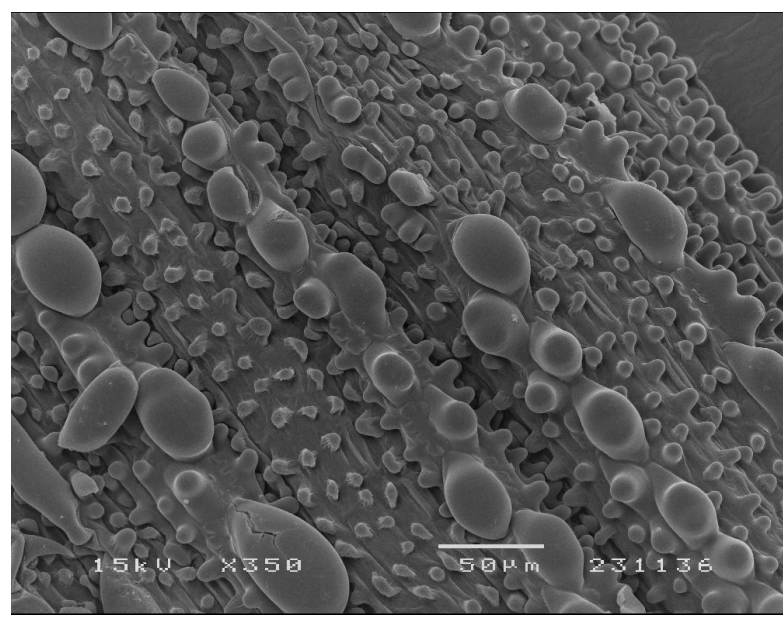

A

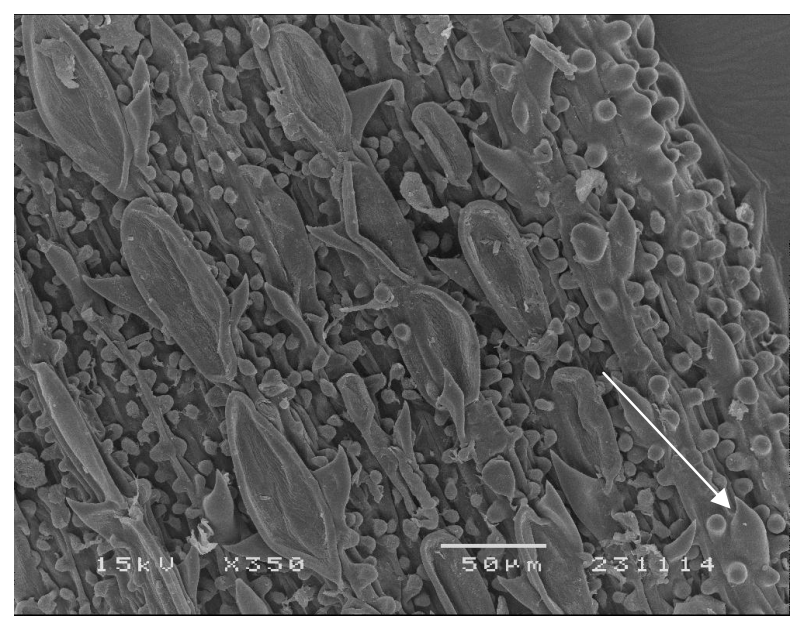

B

Figure 1. A-B: A. agrostidea; A. submerged plant, medium prickles absent on costal zones; B. plant from dried-out pond, medium prickles dense; electron beam accelerating voltage $=15 \mathrm{kV}$.

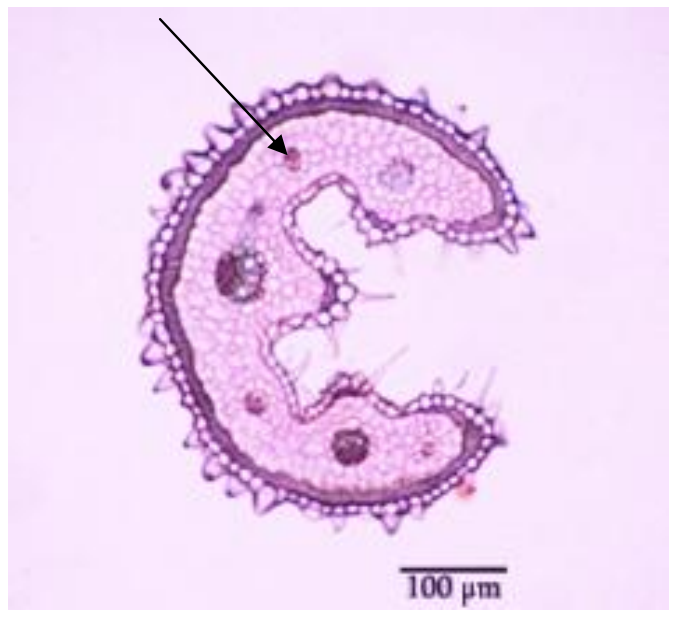

A

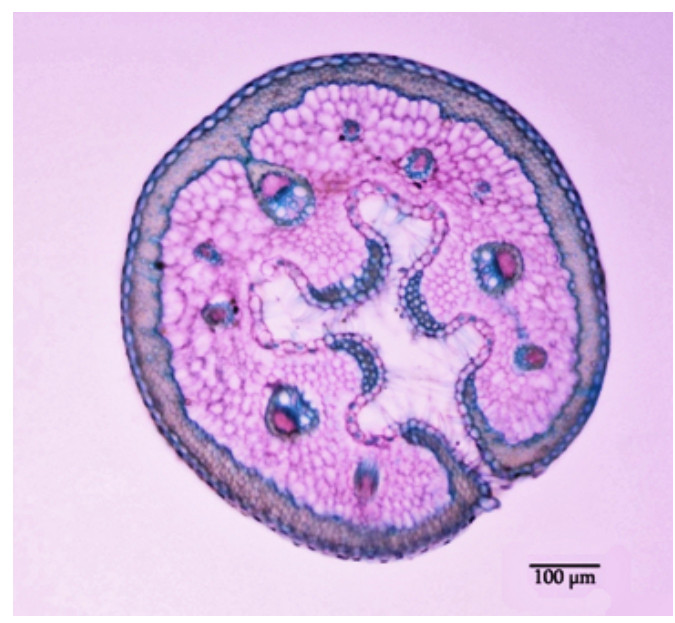

B

Figure 2. A-B: C. canescens; A. plant from high altitude, few and narrow vascular bundles; B. plant from sea level, more and wider vascular bundles; scale bar $=100 \mu \mathrm{m}$. 